\title{
Merck used selective data in Vioxx publications, JAMA says
}

\section{Janice Hopkins Tanne NEW YORK}

Researchers and editors claim in two papers and an editorial this week that Merck, the makers of the arthritis drug rofecoxib (Vioxx), misrepresented study results and used ghostwriters to prepare manuscripts for journal publication.

The authors of the articles have drawn their evidence from thousands of documents released during lawsuits against Merck over adverse events related to the drug (JAMA 2008;299:1800-12, 1813-7, and 1833-5).

Rofecoxib was withdrawn worldwide in September 2004 after a study showed that it doubled the risk of heart attack or stroke if it was taken for more than 18 months (BMJ 2004;329:816).

Merck said in a statement that it "believes that many of the comments in a Journal of the American Medical Association (JAMA) news release and in the 16 April 2008 issue of $J A M A$ related to Vioxx are false, misleading, or lack context."

The dug company's statement said, "The articles, based on analyses of documents conducted by consultants hired by trial lawyers as part of their work in the Vioxx product liability litigation, make allegations similar to those previously advanced by these consultants and related attorneys at trial. Merck is disappointed that we did not have an opportunity to respond to the misleading claims made in these articles prior to their publication."

Merck acknowledged that it used outside medical writers and continues to do so but that it has "clear policies" regarding their supervision by named authors and "explicit policies" regarding disclosure of who contributed to the paper and of financial compensation.

In one of the $J A M A$ articles Bruce Psaty and Richard Kronmal of the University of Washington in Seattle, consultants to the plaintiffs in the action against Merck, said that the company misrepresented the riskbenefit profile of rofecoxib in two published articles about its trials in Alzheimer's disease (Neurology 2004;62:66-71; Neuropsychopharmacology 2005;30:1204-15).

They wrote that Merck's internal analyses of pooled data from the trials "identified a significant increase in total mortality ... with overall mortality of 34 deaths among 1069 rofecoxib patients and 12 deaths among 1075 placebo patients . . . These mortality analyses were neither provided to the FDA [US Food and Drug Administration] nor made public in a timely fashion."

When the FDA raised questions about the safety data submitted by the company, "the sponsor did not bring these issues to an institutional review board for review," Dr Psaty and Dr Kronmal say.

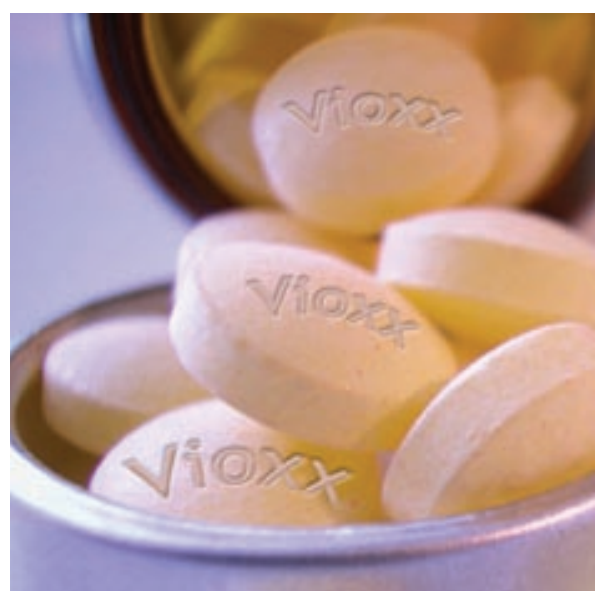

The risk-benefit profile of Vioxx was

"misrepresented" in two published articles

In another $J A M A$ paper Joseph Ross of the Mount Sinai Medical School in New York and colleagues found that Merck employees worked independently or with medical publishing companies to prepare manuscripts about clinical trials. They then recruited external academically affiliated investigators to be authors of the papers, usually as first or second author.

Review articles were often ghostwritten by medical publishing companies, which followed Merck's directions.

Dr Ross and his colleagues say, "Authorship in biomedical publication provides recognition while establishing accountability and responsibility." A guest author does not meet true authorship criteria, while a ghostwriter makes a substantial contribution to the research or writing of a manuscript but is not credited.

\section{Department's denial of free care to asylum seekers was unlawful}

\section{Owen Dyer LONDON}

Department of Health guidelines that instructed health authorities to deny free treatment to failed asylum seekers have been ruled unlawful by a High Court judge.

The test case, involving a Palestinian man with liver disease named only as MrA, could change the entitlement to free health care of about 11000 asylum seekers whose deportation has been delayed after rejection of their application. MrA agreed to return to the West Bank in 2005 when his application for asylum was refused, but his departure has been held up for three years by travel restrictions and problems with his documentation. He sought judicial review of a decision by West Middlesex University Hospital NHS Trust to deny him free treatment, initially lodging his claim in 2006.
Although the health department disputed his right to treatment, after he mounted his legal challenge it agreed to treat him while his case went ahead.

The department's guidelines, issued in 2004, instructed trusts to charge for the treatment of failed asylum seekers who did not meet the legal definition of "ordinarily resident." Those who had been in the United Kingdom for fewer than 12 months did not meet this criterion, the guidelines state.

But Mr Justice Mitting last week ruled that such an interpretation of "ordinarily resident" status had no legal basis. The status is not restricted in time but may be given at the discretion of the authorities, he said, and should be granted to failed asylum seekers who were in the UK legally because of unavoidable delays in their removal. 


\section{Wakefield admits fabricating events at children's party}

\section{Owen Dyer LONDON}

The doctor whose study triggered a collapse in public confidence in the combined measles, mumps, and rubella (MMR) vaccine told a disciplinary panel last week that he made up details of his son's birthday party-at which he took blood samples from several childrenwhen giving a speech in California.

Andrew Wakefield was one of the authors of the 1998 Lancet paper on inflammatory bowel disease and autism. He is now facing a General Medical Council fitness to practise panel, accused of serious professional misconduct, alongside two other authors of the study, Simon Murch and John Walker-Smith.

Dr Wakefield's comments at a press conference announcing the paper, where he linked the MMR vaccine to a risk of autism, led to a public health scare that saw uptake of the vaccine dip below $80 \%$.

The GMC's charges against Dr Wakefield include allegations that, in 1998 while a consultant at the Royal Free Hospital, London, he unethically paid children at his son's 10th birthday party $£ 5(€ 6 ; \$ 10)$ each to give blood samples he wanted for his research.

Last week the GMC panel saw video footage of a speech Dr Wakefield gave in 1999 at a meeting of parents of autistic children called by the Mind Institute of the University of California, Davis, where he jokingly described children fainting and vomiting after giving blood.

"Two children fainted, one threw up over his mother," he told his laughing audience in the clip. "People said to me, you can't do that-children won't come back to your birthday parties. I said we live in a market economy; next year they'll want $£ 10$."

But Dr Wakefield told the GMC panel that he had made up these details to amuse his listeners. "It was the end of a long and rather exacting talk for the parents, and it was an attempt to introduce a little bit of levity," he said. "It was a quip, just a story. The way these stories are told, if the audience responds you tend to respond back. So the story was told. But it had no bearing on the truth at all."

He added that he had been "naive" to think he could take the samples without the permission of an ethics committee.

Dr Wakefield's defence challenged testimony given earlier by Richard Horton, editor of the Lancet, who said that he had not known before the article's publication of Dr Wakefield's work on behalf of MMR litigants.

Dr Wakefield alleged that newly uncovered documents reveal an extensive correspondence between the Lancet and Dawbarns, the firm of solicitors representing MMR claimants. These letters, several months before publication of the 1998 article, described Dr Wakefield's work on behalf of the MMR litigants, he said. While he was "not impugning Dr Horton's honesty," said Dr Wakefield, the documents proved "in my opinion beyond a shadow of a doubt that he was aware of all these factors."

Dr Horton, reached by email while travelling abroad, denied any foreknowledge of the conflict of interest, saying that the correspondence did not make clear Dr Wakefield's role in litigation. The case continues.

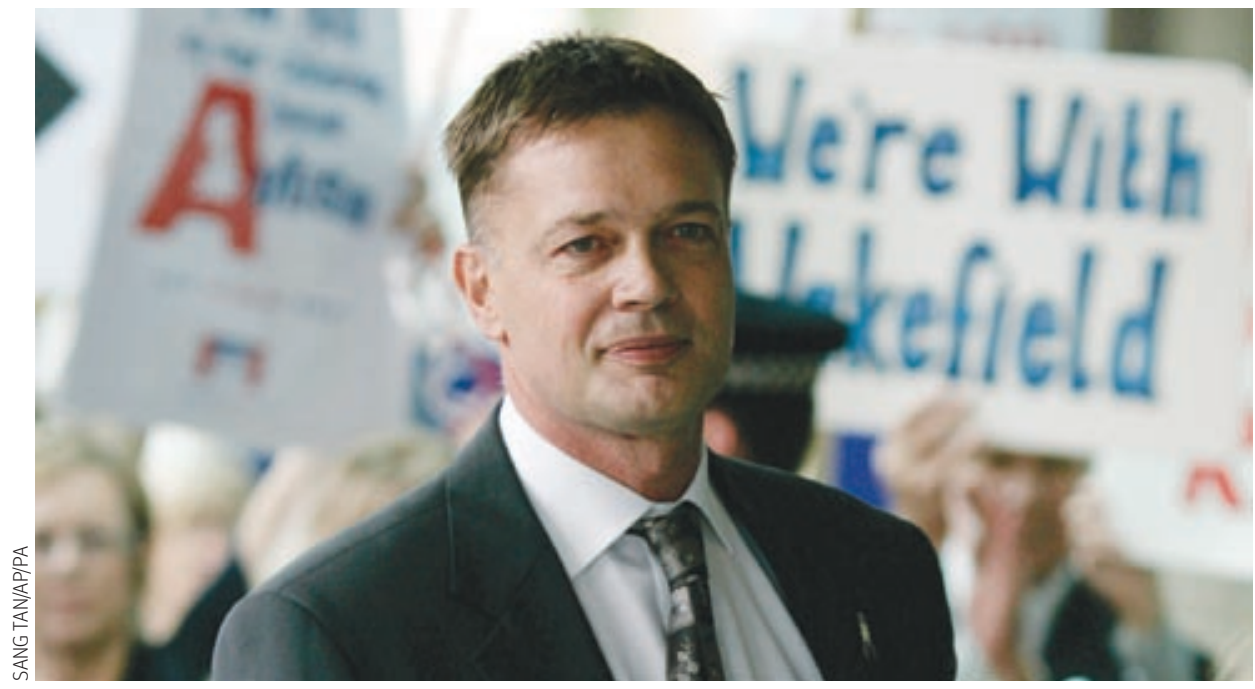

Dr Andrew Wakefield said he was naive to think he could take samples without ethics committee approval

\section{Drug industry lobby}

\section{Bob Burton HOBART}

Australia's leading drug industry lobby group, Medicines Australia, is canvassing options on how to counter what it describes as "challenges" to its "credibility and trust." The move comes after new rules were introduced making it mandatory for drug companies to publicly disclose details of their involvement in meetings and conferences for doctors (BMJ 2008;336:742).

The lobby group's annual one day "members only" conference included presentations from an ethicist on "ethical conduct," a public relations adviser on "shaping a new image," and a market researcher on "moral responsibility and corporate reputation.”

\section{HFEA will defend challenge on hybrid embryo research}

\section{Susan Mayor LONDON}

The Human Fertilisation and Embryology Authority (HFEA), the body that regulates embryo research in the United Kingdom, will "robustly" defend a legal challenge filed with the High Court last week on the HFEA's decision to grant licences for research using hybrid human-animal embryos.

The Christian Legal Centre (a non-denominational group campaigning for Christian values) and Comment on Reproductive Ethics (which describes itself as a public interest group on human reproduction issues) have asked for a judicial review of the HFEA's decision in January to approve research using human-animal cytoplasmic hybrid embryos by scientists at King's College London and Newcastle University (BMJ $2008 ; 336: 177)$.

The claimants filed their petition on two grounds. They claim that the relevant legislation, the Human Fertilisation and Embryology Act 1990, does not allow licensing of human-animal hybrid embryos and, in fact, contains a prohibition on the creation of such embryos. "Therefore, no licence can be granted by the HFEA, and the HFEA acted beyond its powers," they argue.

Secondly, they say that even if the HFEA did have the power to grant a licence, no licence could be granted unless the research meets the HFEA's criteria: that it is "necessary or desirable for one of a number of specified purposes."

Andrea Minichiello Williams, a barrister 


\section{seeks to improve its image after forced disclosures}

In the conference programme the group's chief executive, Ian Chalmers, wrote that "there are serious issues of reputation and trust that we need to address." In an interview with the BMJ he was more circumspect. "I'm not conceding that we have a serious reputation problem," he said, "but we have a responsibility to make sure we understand how others view us."

An August 2006 internal memo from the then chairman of the group, John Young, expressed concern about "the potential ongoing negative publicity" from a new regulatory requirement that details of the cost of individual events be made public every six months (BMJ 2007;335:12-3). A communications plan drafted shortly afterwards for the group by the public relations firm Parker and Partners warned that the regular disclosure reports could force the then government or opposition to back "compulsory regulation" of drug industry marketing rather than supporting the industry's self regulatory code of practice.

However, the recently appointed federal minister for health, Nicola Roxon, made no mention in her keynote address of the controversy over the industry's spending on events for doctors. "I'm not going to go into why it wasn't addressed in the speech," said Sean Kelly, a spokesman for Ms Roxon.

David Bell, the chief executive officer of the Australian Bankers Association, spoke to the conference on lessons from the banking industry's experience in "restoring a tarnished reputation." In 1999 the association was embroiled in controversy after revelations that it had secretly contracted to pay a high profile commercial radio presenter to give the industry favourable coverage. In an interview Mr Bell explained that the banking industry ensures that key politicians are briefed before major issues emerge or announcements are made. "We have a policy of "no surprises,"” he said.

The drug industry is also reaching out to influential journalists. The final conference session was facilitated by Geraldine Doogue, a high profile national television and radio presenter with the Australian Broadcasting Corporation. Ms Doogue was not available for comment. and director of the Christian Legal Centre, said, "We believe the HFEA acted unlawfully in granting licences permitting the creation of human-animal hybrid embryos." She considered that the decision to grant the licences was not justified in law because the proposed scientific techniques had been rendered "unnecessary" and "undesirable" by new technical advances.

She said, "The proposed techniques do not work and raise new scientific problems that will prevent any meaningful research work. When other alternatives to such controversial research already exist, then it cannot be claimed that such new research is either necessary or desirable." Other research techniques that the centre would like to see used are those involving adult stem cells and stem cells derived from umbilical cord.

An HFEA spokeswoman confirmed that it had received papers on the case but could not comment further because of the legal challenge. But she added, "We will be robustly defending the case."

In its original approval of the research applications that are being challenged, the HFEA's licensing committee said that they met its requirements for research that is "necessary or desirable" to increase knowledge about the development of embryos, serious disease, and treatments for serious disease. Members also agreed that the proposed research could not be undertaken without the use of human embryos and that creation of human-animal hybrid embryos was justified because of the lack of available human oocytes.

The Christian Legal Centre's statement is at www.christianlegalcentre.com/view.php?id=274 The HFEA licence committee's minutes are at www. hfea.gov.uk/en/1640.htm.

\section{German parliament liberalises law on stem cell research}

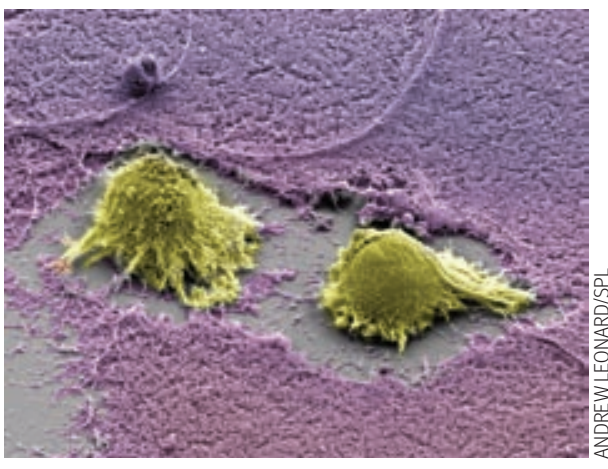

German scientists will now be able to use embryonic stem cells derived from 400 lines

\section{Ned Stafford HAMBURG}

After months of often impassioned public debate Germany's Bundestag has voted to liberalise the nation's law on research involving embryonic stem cells. Researchers say that the change will allow them to more effectively compete-and collaborate-internationally.

The revised law, approved on 11 April, will allow German scientists to import stem cell lines derived from embryos before 1 May 2007, although the process to derive stem cells will still be banned in Germany. Under the old law the import cut-off date was 1 January 2002, meaning that scientists had access to only about 40 outdated stem cell lines. Now they will be able to work with more than 400 lines.

Jürgen Hescheler, head of the Institute of Neurophysiology at the University of Cologne and president of the German Society for Stem
Cell Research, said that he would have preferred no cut-off date. But he admitted that he was happy with the compromise: "You can't always get everything you want. Now we can work with scientists in other countries who are using newer lines."

Resistance to the revision of the law from pro-life groups was intense, particularly the Catholic church, whose top officials in recent months argued loudly against the change. All German political parties called the matter a vote of conscience and did not put pressure on party members.

The final vote cut across party lines, with 346 members voting in favour of the change, 228 against, and six abstaining. A proposal to allow imports of stem cell lines with no cut-off date restriction drew only 126 votes in favour, and a proposal for a complete ban of embryonic stem cell research had only 118 supporters. The defeat of those proposals allowed the compromise proposal with the 2007 cut-off date.

A key figure in the passage of the new law was the research minister, Annette Schavan, a conservative Catholic, who surprised manyand angered Catholic church officials-when last autumn she announced her support for a one-off relaxation of imports. She argued that the change was needed to keep German science globally competitive, and she had strong backing from industry leaders.

Chancellor Angela Merkel had remained almost silent on the issue for the past few months but voted in favour of the change. 


\section{IN BRIEF}

More Americans have died from contaminated heparin: The US Food and Drug Administration reports that 62 deaths since lanuary 2007 have been linked to heparin made from imported Chinese ingredients said to be contaminated with oversulphated chondroitin sulphate. The deaths were due to hypotension or allergic reactions. Heparin from several manufacturers has been recalled in the US, Germany, Denmark, France, Italy, and Spain.

More independent sector treatment centres are to open in England: Three more independent sector treatment centre schemes have been given the go ahead by the Department of Health: two in Greater Manchester and one in Hampshire and the Isle of Wight. Final proposals for a scheme in Avon, Gloucestershire, and Wiltshire will be announced shortly.

Brazilian government acts to control dengue fever: Brazil's health ministry is working to implement control measures after the national total of cases of dengue rose to 120570 , including 647 cases of dengue haemorrhagic fever and 48 deaths so far this year. Half the cases were in the state of Rio de Janeiro.

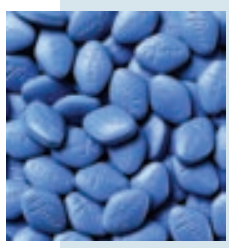

German court rules out insurance for Viagra: Germany's highest court, the Federal Constitutional Court, has ruled that public health insurers, which cover $90 \%$ of the population, have no obligation to cover prescriptions for sildenafil (Viagra), in a lawsuit brought by a man whose dysfunction was caused by diabetes.

Number of liver disease admissions rises in England: From 1990 to 2003 the number of admissions to hospitals in England for chronic liver disease rose by $71 \%$ in men, from 24.9 to 42.4 admissions per 100000 , and $43 \%$ in women, from 19.3 to 27.6 per 100000 . The rise was largely due to alcoholic liver disease, the rate of which has more than doubled, say the authors (Alcohol and Alcoholism doi: 10.1093/alcalc/ agn020).

Centre warns of increase in measles incidence in Europe: The number of cases of measles is rising in Europe. The European Centre for Disease Prevention and Control has warned of a possible "serious situation" and is encouraging people to be vaccinated. So far more than 1300 cases have been reported this year.

\section{$10 \%$ of hospital deaths could be avoided, conference is told}

\section{Henry Creagh LONDON}

Ten per cent of deaths in hospitals may be caused by deficient care, delegates at a London conference were told last week.

This estimate comes from the NHS Institute for Innovation and Improvement, which has been running a project implementing a range of safety measures in certain hospitals. The project has resulted in a $10 \%$ reduction in the number of deaths.

The institute identified certain causes of death that could be tackled. They ranged from incorrect administration of drugs and faulty surgical procedures to postoperative deep vein thrombosis and hospital acquired infections. It identified opiates and warfarin as drugs carrying a high risk of maladministration.

The conference chairman, Hugh Rogers, a senior associate at the institute, said that if the project's changes were put into practice across England they would save 10000 lives a year.

$\mathrm{Mr}$ Rogers told the conference, which was organised by the private events company Healthcare Events, that 25000 people died after surgery every year in England from

\section{US hospitals pass on most of the costs of errors to other payers}

\section{Janice Hopkins Tanne NEW YORK}

US hospitals pass $78 \%$ of the costs of all adverse events and 70\% of the costs of negligent injuries to other payers, says a report by Harvard researchers. Their report, published in the Journal of Empirical Legal Studies (2007;4:835-60), says that these other payers include the Medicare insurance plan for elderly people, health insurance companies, disability insurance programmes, and injured patients and their families.

Medical errors cost $\$ 17$ bn $(£ 8.6 \mathrm{bn}$; $€ 10.7 \mathrm{bn})$ to $\$ 29 \mathrm{bn}$ a year in the United States, estimates the Institute of Medicine. Advocates for patients' safety have tried to persuade hospitals that the cost of malpractice lawsuits and adverse events are a "business case" for improving safety, the authors of the report write. However, the study found that hospitals shift most of the costs of injury to other parties and therefore have little economic incentive to improve patient safety.

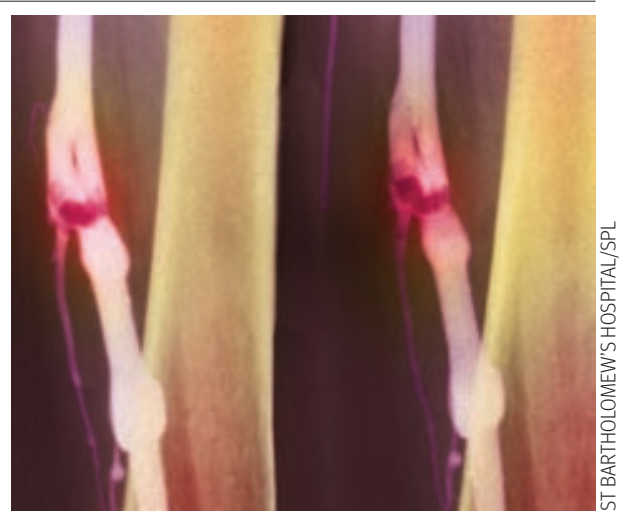

More than $\mathbf{2 5} 000$ people die annually in England from deep vein thrombosis after surgery

deep vein thrombosis alone. He asked: "If we could get [deep vein thrombosis] prophylaxis totally right, how many of these people could we save?"

Leadership was an important factor in implementing good practice, Mr Rogers said, but it was vital that all NHS staff members were motivated and involved in the process.

Referring to the Healthcare Commission's 2007 national NHS staff survey (available at www.healthcarecommission.org.uk, he said, "A recent survey showed that only $46 \%$ of NHS staff believed that patient care is the main aim of their trust. That is woeful and shows a clear lack of leadership."

The report's lead author, Michelle Mello, a professor at the Harvard School of Public Health, said that the authors used previously collected data on the costs of 465 injuries, including 127 negligent injuries, at 24 hospitals in Utah and Colorado in 1992.

The average cost per injury was $\$ 58766$ for all adverse events and $\$ 113280$ for negligent injuries. But the study found that each adverse event cost the hospitals an average of only $\$ 2013$, and each negligent injury cost an average of $\$ 1246$. The remainder of the costs was passed on to insurers, patients, and their families.

\section{How to cheat at anatomy}

Annabel Ferriman BMJ

A cookbook to satisfy the curiosity of anatomists as well as foodies is helping Nottingham students learn about biomechanics.

Donal McNally, scientific director of the Institute of Biomechanics at Nottingham University, has produced The Anatomy CookBook: A Dissection Guide with Recipes because, he says, "Ifyou have 


\section{Dutch doctors are told they must abide by strict rules if they use complementary medicine}

\section{Tony Sheldon UTRECHT}

Dutch doctors are given a new code of practice on complementary medicine in the same week as the Dutch appeal court ordered the prosecution of two doctors and a faith healer over their treatment of Sylvia Millecam, a comedian, who died from breast cancer in 2001 (BMJ2007;335:13).

The public prosecution service originally dismissed the case against the three, accepting that Ms Millecam made a conscious choice for alternative care. But the Amsterdam court believes that questions remain over how Millecam's decision was made.

The court said that she had placed trust in the doctors' and the faith healer's statements that her disorder was not breast cancer but a bacterial infection. It said that the three "cannot deny their own responsibility in referring to the choices made by a patient, if this patient has not been correctly or fully informed by them."

The appeal was brought by two organisations, the Dutch Association against Quackery and the Society of Sceptics.
The judgment comes as the Dutch Medical Association adopts strict new rules governing doctors who practise alternative treatments. Doctors must adhere to the best available scientific proof, offering alternative treatment only under strict conditions, the rules say.

Doctors must not avoid or delay mainstream treatment, must inform the patient fully about the treatment, and must not offer care that would harm the patient.

Harm is defined broadly and includes not giving the patient false hope or false information about the known effectiveness of the treatment and not advising against treatment that is generally accepted within the profession.

The association's chairman, Peter Holland, welcomed the appeal court decision in the Millecam case, saying that the

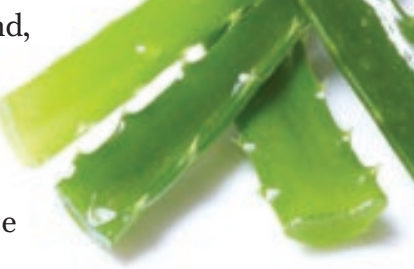

doctors had "misled" their patient. The aim of his association's new rules was to ensure that patients can maintain trust in their doctor. "We now have clear requirements of care for alternative treatment."

The action by the doctors' professional body comes after two damning judgments by medical disciplinary boards in which doctors are judged to have seriously misled their patients.

Aloe vera: In the Millecam case the new rules Central Disciplinary Tribunal apply for Medical Care last year struck off from the medical register a doctor involved in her treatment. The doctor had treated her with "magnetic field therapy."

In January a doctor was struck off by the Eindhoven Regional Disciplinary Tribunal after he referred patients to an orthomolecular therapist. She diagnosed and treated patients with Lecher antennae, a kind of divining rod.

\section{Officials knew tests were faulty two years before revealing it}

\section{David Spurgeon QUEBEC}

A public inquiry is under way into serious errors in testing for breast cancer in Newfoundland and Labrador that resulted in 383 of 1013 patients missing out on treatment they should have had.

At the opening of the inquiry in March it was estimated that 108 patients who died had not received adequate treatment www.cbc. $\mathrm{ca} /$ news/background/cancer/inquiry.html).

The commission of inquiry, headed by Honourable Justice Margaret Cameron, is looking into problems with oestrogen and progesterone hormone receptor tests conducted between 1997 and 2005. The tests were carried out to determine whether a patient's breast cancer was oestrogen receptor positive or progesterone receptor positive and therefore required treatment with antihormone drugs.

Such tests were suspended in 2005 after a patient who initially tested negative was retested and found to test positive. Retesting

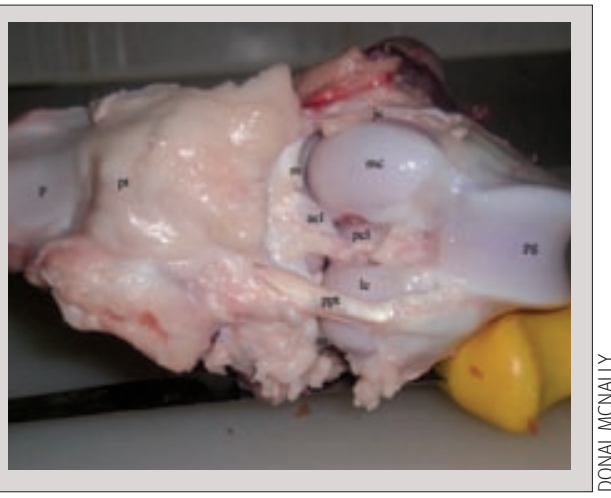

of another 25 patients who had been declared to have a negative result showed that almost half tested positive.

It was only after a class action lawsuit was brought against it that in May 2007 Eastern Health, the Newfoundland and Labrador health service, released information concerning how many patients had died after being given the wrong treatment and how many patients had been informed when a problem was first detected.

The inquiry was told that Eastern Health was aware that its breast cancer testing lacked accuracy two years before it publicly revealed the extent of the problem. It was also told that Eastern Health's insurance company lawyer, Daniel Boone, of the firm Stewart McKelvey Sterling Scales, discouraged the health authority from sending letters to patients telling them of problems with the tests to avoid the risk of litigation against it. $\mathrm{Mr}$ Boone is yet to give evidence to the inquiry.

Audits of Eastern Health identified staff incompetence, poor quality control, deficient procedures, and general neglect of the subspecialty of pathology as problems.

The inquiry's final report and recommendations are due by the end of July. 


\section{New combined pill to treat malaria is launched}

\section{John Zarocostas GENEVA}

A new low cost, first line, fixed dose combination drug to treat uncomplicated falciparum malaria in Latin America and South East Asia is expected to lower the number of cases of the disease and reduce the number of hospitalisations.

The combination of artesunate and mefloquine in a single tablet has been produced as a "non-exclusive, not for profit public good," said the Drugs for Neglected Diseases Initiative, which coordinated the project.

"The drug combination in the same tablet will improve the management of cases," said Bernard Pecoul, executive director of

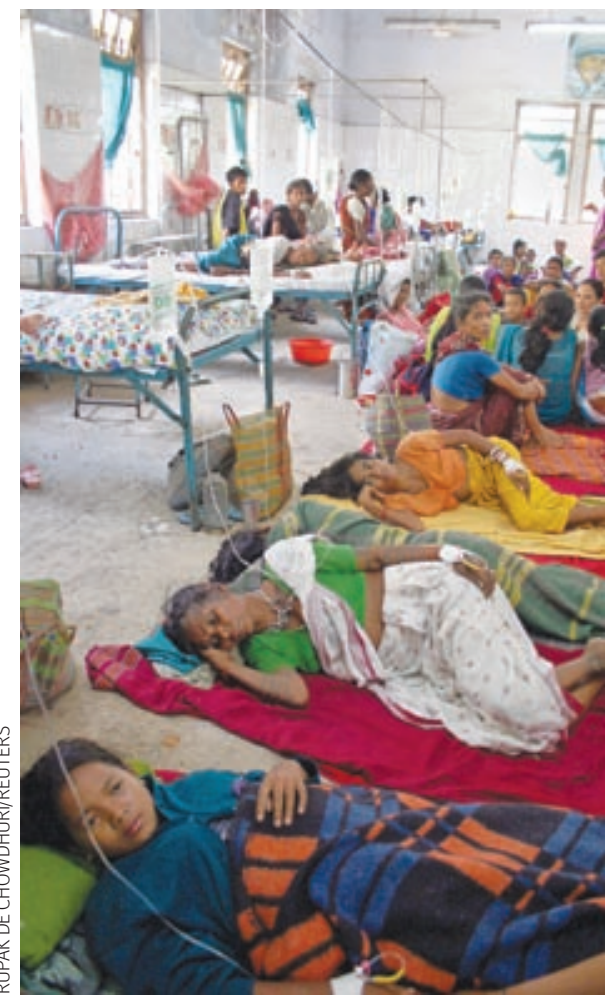

Malaria patients such as these in Naxalbari, West Bengal, are expected to benefit from the new pill the initiative, which is the joint project of seven organisations, including the charity Médecins Sans Frontières and France's Pasteur Institute.

The new product, which avoids the need for a two tablet regimen, "will make it more possible to use [treatment] more simply in the field," said Jean-René Kiechel, the initiative's senior project manager for malaria. The fixed dose would also help ensure compliance, he said.

The combination is one of four artemisinin based combination treatments recommended by the World Health Organization since 2001. In 2006 WHO also issued guidelines that recommended the use of fixed dose combinations wherever possible.

The initiative's experts listed some of the new drug's advantages, including the simple regimen, its low cost and easy to use packaging, and long shelf life. Dr Kiechel said that they were aware of the reported adverse reactions to mefloquine, including nausea, headache, nervousness, and insomnia and that they had been monitoring its combined use with artesunate, although in a separate tablet.

"We have collected data on more than 5500 patients, and the tolerability of this form of treatment is very acceptable," he said.

The new product, for adults and children, comprises a daily dose of one or two small tablets to be taken daily for three days. Its packaging is colour coded to allow easy identification of the different dosages for the four age categories: infants, toddlers, children, and adults.

Basing the dosage on age rather than weight will make it easier to administer the drug in remote areas where scales are often lacking, the initiative said.

Another advantage of the drug is that it has a shelf life of three years in tropical conditions.

It will be made available at the cost price of $\$ 2.50(£ 1.30 ; € 1.60)$ for the full adult treatment throughout Latin America and South East Asia over the course of 2008 and 2009. Brazil's public pharmaceutical company Fiocruz will be responsible for production in Brazil and the rest of South America, and the Indian manufacturer of generic drugs Cipla will produce the drugas a result of technology transfer from the Brazilian firm-for Asia.

Dr Kiechel said that the combined treatment seemed to be effective even in Thailand, where some areas have mefloquine resistance.

An estimated 228000 cases of falciparum malaria were reported in 2006 in Latin America, the initiative said, and 1.5 million cases were reported in South East Asia in 2005.

Dr Pecoul said that preliminary results of a large, one year intervention study in three municipalities in the Amazon basin, funded by Brazil's Ministry of Health and the PanAmerican Health Organization, showed that after the new drug was introduced the number of cases of falciparum malaria fell by $70 \%$, in comparison with the year before. The study also showed that the number of hospitalisations related to malaria fell by $62 \%$.

"This is good news for patients around the world, as more affordable and easy to use, fixed dose treatments for malaria are needed," said Nick White, professor of tropical medicine at Oxford University.

"With effective, safe, easier to use, and better tolerated treatments like this becoming available, it's ever more urgent that we make sure these treatments reach the patients who actually need them," he added.

The drug cost $€ 7.8 \mathrm{~m}$ to develop, said the initiative, and funding came from the European Union, the governments of the UK, France, Spain, and in kind from Fiocruz.

\section{UK psychiatrists offer help in teaching mental health care}

\section{Owen Dyer LONDON}

British psychiatrists are stepping in to help fill the gaps in Iraq's mental health services, through a training programme for Iraqi health professionals led by the Royal College of Psychiatry.

Seven fellows and members of the college will travel this week to Erbil, capital of the Kurdish regional government zone, to take part in a continuing medical education conference that was organised with Iraqi local and national health authorities, the American Psychiatric Association, and the non-profit humanitarian organisation the International Medical Corps.

Riadh Abed, medical director of Rotherham, Doncaster and South Humber Mental Health NHS Foundation Trust and one of the programme's organisers, said that the conference aimed to teach the basics of mental health care to doctors and other health professionals who have often had to take on such work with no training. It will be the second such conference.

After a pilot programme in Erbil last year the college signed a memorandum of understanding with the Kurdish government and the central government in Baghdad. "Five of us went for two days last year," said DrAbed, "and we thought it was a very useful exercise. This year's programme is a bit more ambitious."

Erbil, the safest and wealthiest city in Iraq, has become a focal point for outside efforts to counter the country's severe medical brain drain and has hosted a permanent continuing medical education centre 


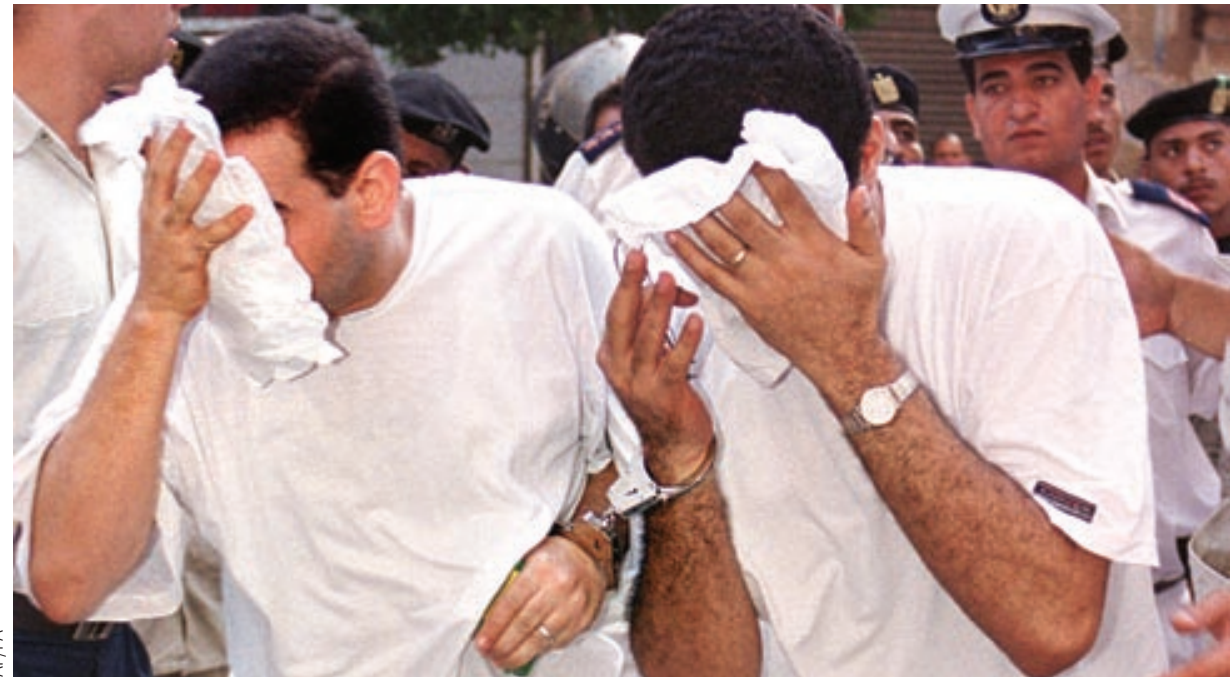

Egyptian men accused of having gay sex hide their faces before a trial in 2001

\section{Egyptian doctors who took part in HIV testing "violated medical ethics"}

Peter Moszynski LONDON

The arrest and forcible medical examination in Egypt of men who were suspected of being practising homosexuals have outraged doctors and human rights groups worldwide.

Dozens of men were recently arrested in a crackdown against gay men that began last October. Those found to be HIV positive were detained in hospital and chained to hospital beds for several months until a court order was obtained to have the chains removed.

Last week a trial of men accused of homosexual acts went ahead in Cairo, despite objections from more than 100 campaigning organisations, including Amnesty International, Human Rights Watch, and Physicians for Human Rights.

Four HIV positive men were convicted of the "habitual practice of debauchery," a term used in Egypt's legal system to denote consensual homosexual acts. They were sentenced to three years in prison followed by three years of close police supervision.
A fifth man who was HIV negative was also convicted and received the same sentence.

Susannah Sirkin, deputy director of Physicians for Human Rights, said, "This case involves shocking abuse of human rights in addition to flagrant violation of universally recognised medical ethics."

A letter to the Egyptian Ministry of Health and Population, jointly signed by 117 different rights groups, said that doctors employed by the ministry "subjected the men to HIV tests without their consent."

The letter said, "Doctors from the Forensic Medical Authority forcibly subjected the men to intrusive, medically valueless, and abusive forensic anal examinations to 'prove' they had engaged in homosexual conduct.

Neither Egypt's Ministry of Health and Population nor the Doctors' Syndicate, the doctors' professional association, has responded to the campaigners' letter. A copy of the letter is at http://hrw.org/english/ docs/2008/04/07/egypt18439.htm.

\section{Americans die each year because of lack of insurance}

\section{Janice Hopkins Tanne NEW YORK}

Many more Americans die because of a lack of health insurance than previously thought, concludes a new state by state study by Families USA, a non-profit organisation that advocates health care for all Americans.

More than 26260 Americans aged 25 to 64 died in 2006 because they lacked health insurance-more than twice as many as were murdered, Families USA said. In the seven years from 2000 to 2006 an estimated 162700 Americans died because of lack of health insurance.

Families USA said, "The number of uninsured Americans reached 47 million in 2006, and it continues to rise. For many of the uninsured, the lack of health insurance has dire consequences. The uninsured face medical debt, often go without necessary care, and even die prematurely."

In 2002 the US Institute of Medicine estimated in its report Care Without Coverage: Too Little, Too Late that 18000 adults aged 25 to 64 died because they did not have health insurance. The Urban Institute, a non-partisan economic and social policy research institute, estimated that 22000 to 27000 adults in the same age group died in 2006 because they lacked insurance.

Families USA reported that it generated "the first ever state-level estimates of the number of deaths due to lack of health insurance." It applied methods used by the Institute of Medicine and the Urban Institute to data at the state level.

Uninsured people are generally sicker and die earlier than people who have insurance, Families USA said.

Dying for Coverage is available at www.familiesusa.org.

\section{to colleagues in Iraq}

for five years. The Royal College of Paediatrics and Child Health held a training workshop there last year, and training courses have also been held in orthopaedics, ophthalmology, and otolaryngology. Erbil is also a haven to many of Iraq's displaced doctors.

Erbil is a natural choice because it offers security, said Dr Abed; but a corollary of this is that most help reaches the areas least ravaged by war. "Last year, of 65 [people] who attended the conference, 55 were from Kurdistan. Travel in Iraq is so difficult and dangerous, it's very hard for people to make it."

The conference will have modules on stress, mood disorders, somatoform disorders, cognitive impairment in elderly people, mental health in prison, and substance misuse.

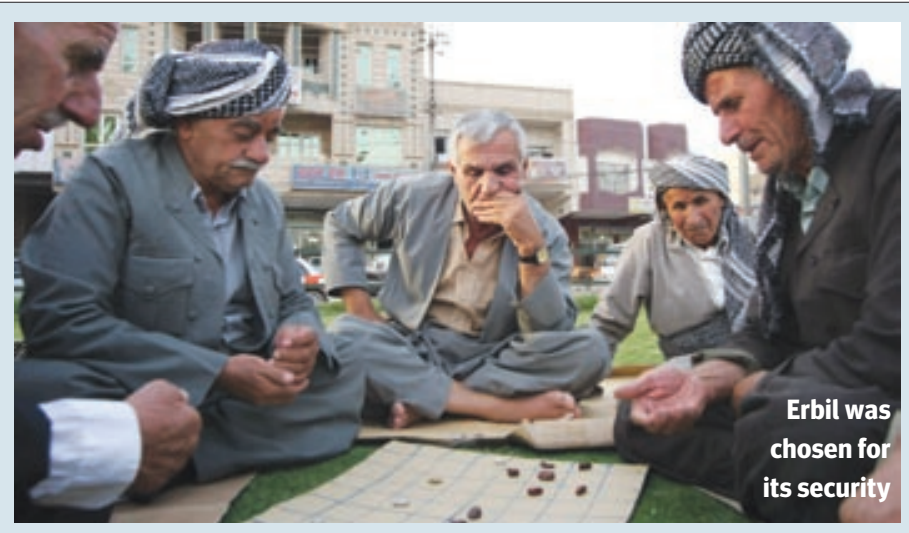

